\title{
Endogenous Cardiac Steroids in Bipolar Disorder: State of the Art
}

\author{
Rif S. El-Mallakh ${ }^{1, *}$, Vishnu Priya Sampath ${ }^{2}$, Noa Horesh ${ }^{2}$ and David Lichtstein ${ }^{2, *}$ \\ 1 Mood Disorders Research Program, Depression Center, Department of Psychiatry and Behavioral Sciences, \\ University of Louisville School of Medicine, Louisville, KY 40202, USA \\ 2 Department of Medical Neurobiology, Faculty of Medicine, The Institute for Medical Research, Israel-Canada, \\ Hadassah Medical School, The Hebrew University, Jerusalem 9112102, Israel; vishnulifebt@yahoo.com (V.P.S.); \\ noa.rosenthal1@mail.huji.ac.il (N.H.) \\ * Correspondence: rselma01@louisville.edu (R.S.E.-M.); davidli@ekmd.huji.ac.il (D.L.)
}

check for updates

Citation: El-Mallakh, R.S.; Sampath, V.P.; Horesh, N.; Lichtstein, D. Endogenous Cardiac Steroids in Bipolar Disorder: State of the Art. Int. J. Mol. Sci. 2022, 23, 1846. https:// doi.org/10.3390/ijms23031846

Academic Editors: Alexei Y. Bagrov and Olga V. Fedorova

Received: 20 December 2021

Accepted: 1 February 2022

Published: 6 February 2022

Publisher's Note: MDPI stays neutral with regard to jurisdictional claims in published maps and institutional affiliations.

Copyright: (c) 2022 by the authors. Licensee MDPI, Basel, Switzerland. This article is an open access article distributed under the terms and conditions of the Creative Commons Attribution (CC BY) license (https:// creativecommons.org/licenses/by/ $4.0 /)$.

\begin{abstract}
Bipolar disorder (BD) is a severe psychiatric illness with a poor prognosis and problematic, suboptimal, treatments. Treatments, borne of an understanding of the pathoetiologic mechanisms, need to be developed in order to improve outcomes. Dysregulation of cationic homeostasis is the most reproducible aspect of $\mathrm{BD}$ pathophysiology. Correction of ionic balance is the universal mechanism of action of all mood stabilizing medications. Endogenous sodium pump modulators (collectively known as endogenous cardiac steroids, ECS) are steroids which are synthesized in and released from the adrenal gland and brain. These compounds, by activating or inhibiting $\mathrm{Na}^{+}, \mathrm{K}^{+}$-ATPase activity and activating intracellular signaling cascades, have numerous effects on cell survival, vascular tone homeostasis, inflammation, and neuronal activity. For the past twenty years we have addressed the hypothesis that the $\mathrm{Na}^{+}, \mathrm{K}^{+}$-ATPase-ECS system may be involved in the etiology of $\mathrm{BD}$. This is a focused review that presents a comprehensive model pertaining to the role of ECS in the etiology of BD. We propose that alterations in ECS metabolism in the brain cause numerous biochemical changes that underlie brain dysfunction and mood symptoms. This is based on both animal models and translational human results. There are data that demonstrate that excess ECS induce abnormal mood and activity in animals, while a specific removal of ECS with antibodies normalizes mood. There are also data indicating that circulating levels of ECS are lower in manic individuals, and that patients with BD are unable to upregulate synthesis of ECS under conditions that increase their elaboration in non-psychiatric controls. There is strong evidence for the involvement of ion dysregulation and ECS function in bipolar illness. Additional research is required to fully characterize these abnormalities and define future clinical directions.
\end{abstract}

Keywords: bipolar disorder; endogenous cardiac steroids; endogenous ouabain; ouabain; $\mathrm{Na}^{+}, \mathrm{K}^{+}$-ATPase

\section{Introduction}

Type I bipolar disorder (BD) is a severe psychiatric illness that manifests as extreme variations in mood and energy, usually labelled as mania and depression, interspersed over a euthymic or dysthymic baseline [1]. The disorder afflicts approximately $1 \%$ of people [2,3], with documented suboptimal treatments and a host of undesirable outcomes related to both the disease and its treatment $[4,5]$. Despite over 60 years of directed effort, the pathoetiology of the illness remains unknown [3], but multiple clues have emerged that continue to inform ongoing research. The illness is viewed as multifactorial, involving elements (of development and neuroplasticity, inflammation, and aberrant modulation of brain function and circuitry) that are mediated by gene and environment interaction through multiple inherited genes and multiple altered epigenetic changes [3,6-8]. However, the absence of a centralized unifying model contributes to the fragmented, siloed, fashion of current pathophysiologic research. In this article, we propose a mechanism of pathophysiology 
that incorporates much of the translational and clinical data, and, in addition to focusing research efforts, also leads to potential novel treatment options.

Among the most reproducible findings in bipolar illness, we observe the dysregulation of control of the electrically important ions sodium $\left(\mathrm{Na}^{+}\right)$, potassium $\left(\mathrm{K}^{+}\right)$, hydrogen (proton, $\left.\mathrm{H}^{+}\right)$, and calcium $\left(\mathrm{Ca}^{2+}\right)$ [9]. Ion regulation spans across all of the proposed mechanisms pertaining to pathogenesis of abnormal moods in bipolar illness, and it spans across all successful treatment options. For example, in an analysis of susceptibility loci, Askland found that approximately $74 \%$ of known loci involve genes related to ion regulation, or what she refers to as neuroelectrical genes [10]. By comparison, genes involved in any neurotransmitter pathway account for only about $58 \%$ of the susceptibility loci, and the monoamines account for only 31\% [10]. A similar conclusion is reached when genome wide association studies (GWAS) are explored [11]. The only animal models of bipolar illness, meeting all validity criteria, create ion transport abnormalities [12-14]. Additionally, nearly all interventions, effective in mania or mood stabilization, reduce intracellular sodium either directly or indirectly [15-17]. Changes in sodium pump activity are associated with changes in mood state $[18,19]$, and endogenous cardiac steroids (ECS), that can determine sodium pump activity, are dysregulated in patients with BD $[11,20]$.

In this review, we summarize the data implicating ECS in the pathophysiology of $\mathrm{BD}$, determine necessary future directions, and reflect on treatment development as a consequence of this work.

\section{Results and Discussion}

Cardenolides, such as ouabain and digoxin, and bufadienolides, such as bufalin, are steroids originally identified in plants (Digitalis, Strophantus) and toads (Bufo), which have been used for hundreds of years in Western and Eastern medicine to treat heart failure, arrhythmias, and other maladies. In the past 25 years, the cardenolides ouabain and digoxin, and the bufadienolides 19-norbufalin, marinobufagenin, and cinobufagenin were identified as normal constituents of mammalian tissues, including the brain [21-24]. These compounds, collectively termed endogenous cardiac steroids (ECS), are synthesized in the adrenal and hypothalamus of mammals [25-27], and they are considered a new class of hormones implicated in many physiological and pathophysiological mechanisms, including cell growth and cancer, vascular tone homeostasis, blood pressure, hypertension, natriuresis, heart contractility, and inflammation [22,24,28].

These mammalian ECS resemble non-mammalian compounds in their ionotropic effects, presumably due to inhibition of the sodium, and potassium-activated adenosine triphosphatase, or sodium pump $\left(\mathrm{Na}^{+}, \mathrm{K}^{+}\right.$-ATPase) [29]. However, at low physiologic concentrations $(\mathrm{nM})$, these compounds have been shown to stimulate pump activity [30-33]. Importantly, the interaction of ECS with the $\mathrm{Na}^{+}, \mathrm{K}^{+}$-ATPase results not only in the inhibition of the ion pumping function, but causes the activation of several signal transduction cascades, including mitogen-activated protein kinase (MAPK), extracellular signal-regulated kinase (ERK), protein kinase B, and oroto-oncogene tyrosine-protein kinase pathways [34,35]. In addition, a substantial body of studies has demonstrated that ECS also act by directly and indirectly affecting the activity of the nuclear receptor superfamily of transcription factors [36,37].

To date, the most studied ECS is the endogenous ouabain (EO); a compound that is similar or identical to the plant steroid. Based on its immunoreactivity with anti-ouabain antibodies, this compound has been shown to be present in mammalian brain and CSF, and it is considered a potential neuromodulator [22,38-40].

It is important to note that there remains some debate regarding the exact structure of EO [41]. Central to this debate, there is difficulty measuring the picomolar concentrations that exist in mammalian systems using direct chemical methods [42]. Notably, the evidence for the existence of EO is quite overwhelming, and the dispute is focused on the exact structure of this steroid [27]. 
The synthetic pathways of ECS are not established, but it is known that cholesterol (which may be reduced in the brains of patients with bipolar illness [43]) is needed for ECS/EO production [27], and the pathway may involve pregnenolone and progesterone as intermediate steps [42]. Pregnenolone levels may be reduced in the cerebrospinal fluid of individuals with a diagnosis of mood disorder, and this reduction may be in relation to the severity of their symptoms [44]. Rapid elevations in plasma levels of ECS, as occurs with exhaustive exercise of normal controls [45], may occur due to the release of bound steroids from a carrier protein [46].

Despite the limited available data on the metabolism of ECS in general, and EO in particular, these compounds are referred to by some as "a hormone family" [21,27,47-52]. However, at the same time, as is evident from the lack of reference in textbooks and reviews, these steroids are ignored almost completely by mainstream biochemists, physiologists, and endocrinologists. We pointed out the crucial importance of deciphering the biosynthetic pathway of ECS close to ten years ago [53], but this issue remained the Achilles heel of this field of research.

At experimental or pharmacologic micromolar concentrations, exogenously administered ouabain inhibits the activity of the sodium pump. However, at physiologic picomolar to nanomolar concentrations, EO increases sodium pump activity [30-33]. In notable cases, when there are documented increases of the plasma levels of $\mathrm{EO}$, the total levels remain below concentrations that inhibit sodium pump activity [54]. At the low concentrations, EO also appear to activate second messengers of the Src kinase-, ERK1/2-, and Akt-mediated pathways or the sodium-proton exchanger 1 (NHE1) [54-57].

Activation of the sodium pump appears to be an essential feature in reducing central nervous system inflammation [58]. If sodium pump activity is blocked in glial cells, inflammatory pathways are activated in the presence of lipopolysaccharides [58].

\subsection{Role of Exogenous CS and ECS in Animal Models of Mood Disorders}

The process of modeling psychiatric disorders in animals is difficult because of the subjective nature of many psychiatric symptoms. Robbins and Sahakian set forth three requirements for an acceptable animal model of a psychiatric disorder [59]. First, they proposed "face validity," in which they noted that the model must share the pathophysiological changes known to occur in the human condition. Second, they required "construct validity," for which they required that the model display similar behavioral manifestations as the human disease. Finally, they defined "predictive validity," in which the induced abnormal behavior responds to medications that improve the symptoms in afflicted humans [59].

The most commonly used model of mania pertains to administration of amphetamine to rats [60] or mice [61]. While this model does not fulfill Robbins and Sahakian's criteria (it is actually an animal model of substance abuse), it has long been used as the animal model for mania. Mice receiving $5 \mathrm{mg} / \mathrm{kg}$ of amphetamine, by intraperitoneal (IP) injection, developed hyperactivity immediately after injection; however, co-administration of intracerebroventricular (ICV) anti-ouabain antibodies normalized the amphetamineinduced hyperactivity [62]. ICV anti-ouabain antibodies alone had no effect [62]. Amphetamine was associated with a $300 \%$ increase in brain levels of ECS [62]. This may increase $\mathrm{Na}^{+}, \mathrm{K}^{+}$-ATPase activity in the brains of rats [63], or reduce $\mathrm{Na}^{+}, \mathrm{K}^{+}$-ATPase activity if the rats were fed a diet, rich in hydrogenated vegetable fats, which is rich in trans fatty acids [64]. Additionally, amphetamine, when administered to rhesus monkeys, upregulates the $\alpha 3$ isoform of the sodium pump [65]. In mice, ICV administration of anti-ouabain antibodies appears to inhibit the increase in brain ECS while preventing the associated hyperactivity [62].

Similarly, sterile inflammation appears to be a characteristic of bipolar disorder pathophysiology [66]. Chronic inflammation may induce oxidative stress [67]. In addition to playing a role in the genesis of symptoms, these conditions may also be responsible for comorbid medical conditions $[66,68]$. Cardiac steroids appear to mediate elaboration of oxidative stress [34], and the dramatic increase of EC in amphetamine treated rats 
may increase inflammation and oxidative stress as reflected by the increase of superoxide dismutase (SOD) activity in these animals [69]. Treatment with anti-ouabain antibodies normalizes SOD in amphetamine-treated mice [69].

Despite these findings pertaining to the amphetamine model, animal models in which the sodium pump is rendered dysfunctional, either by using ICV injections of ouabain [70-72], or by knocking down the $\alpha$ [73] or $\alpha 3$ [74-76] isoforms of the sodium pump, fulfill all three validity criteria for an animal model of a psychiatric illness [13]. These models mimic the abnormalities documented in bipolar patients, including reduced sodium pump activity, increased intracellular sodium [13], and CNS hypometabolism [77]. Importantly, these are the only animal models in which the same abnormality can produce both manic-like behaviors [71] and depressive-type behaviors [78]; thus, they are the best models we have of BD [13].

In Flinders Sensitive Line (FSL) of genetically depressed rats, ICV administration of $50 \mu \mathrm{g}$ of anti-ouabain antibodies significantly reduced depressive behaviors [79]. These same antibodies halved the concentration of ECS in ex vivo samples of human cerebrospinal fluid (SCF) [79].

A reduction of sodium pump activity, via administration of exogenous ouabain or by genetic knockout, serves as an animal model of mania and depression. Conversely, removal of ECS in animals with anti-ouabain antibodies appears to reduce manic symptoms. While these two observations appear to contradict each other, it should be noted that the former (reducing sodium pump) is being performed on a normal animal, while the later (removing EO with anti-ouabain antibodies) is being performed on a symptomatic animal.

\subsection{Role of ECS in Humans Mood Disorders}

ECS appear to play some role in the pathophysiology of BD. Patients with type I bipolar illness display reduced circulating EC when they are manic compared to healthy controls $(143.6 \pm$ S.E.M. 20.94 vs. $296.6 \pm 12.76$ pg digoxin equivalents $/ \mathrm{mL}$, respectively, $\mathrm{F}=4.77$, $p<0.05)$, but not compared to euthymic bipolar subjects $(213.8 \pm 86.92, p=0.77)$ [80]. Furthermore, bipolar patients appear to be unable to increase production of EO based on physiologic need. They do not display the seasonal variation in EO levels that has been demonstrated in healthy controls (higher concentrations in the Spring, Summer, and Fall, and lower levels in Winter, versus low levels all year long in patients with bipolar disorder [80]). More importantly, euthymic patients with bipolar illness do not increase circulating EO in the setting of exercise to exhaustion, as occurs with matched non-bipolar controls [81] or the general population [45]. It has been proposed that sleep deprivation, which is associated with increased production of $\mathrm{EO}$ and corticosterone in mice [82], might be a trigger for a manic switch in bipolar subjects [21,83]. As little as $24 \mathrm{~h}$ of sleep deprivation in humans is enough to increase serum cortisol [84-86] and manic-like symptoms [87].

There is direct evidence pertaining to the involvement of both the sodium pump and ECS in the CNS of patients with BD. An allelic association between BD and a $\mathrm{Na}^{+}$, $\mathrm{K}^{+}$-ATPase $\alpha 3$ subunit gene $(A T P 1 A 3)$ has been reported [88]. In comparison to nonpsychiatric controls, the $\alpha 3$ subunit may be specifically under-expressed in neurons that release gamma aminobutyric acid (GABA) in the parietal cortex of patients with bipolar illness [89]. The parietal cortex of patients with bipolar illness may have fewer ouabain binding sites than non-psychiatric controls [90]. Subsequently, we have demonstrated a significant association with BD of six single SNPs in the three genes of the $\mathrm{Na}^{+}, \mathrm{K}^{+}$-ATPase $\alpha$ isoforms. Haplotype analysis of the $\alpha 2$ isoform showed a significant association with two loci haplotypes pertaining to $\mathrm{BD}$, suggesting that this enzyme plays a role in the etiology of the disease [91], and, indeed, this isoform appears to be reduced in the temporal cortex of individuals with bipolar disorder [92], but $\alpha 2$ and $\alpha 3$ may be increased in the prefrontal cortex [20].

When EO has been measured directly in the prefrontal cortex (PFC), it has been found to be at the same level as non-psychiatric controls; however, this finding appears 
to be driven by two outlier patients with EO levels more than three times higher than the average for the entire group [20]. Interestingly, smoking is associated with reduced PFC EO levels [20], and this is important because individuals with bipolar illness are more than twice as likely to smoke as the general population [93]; the smoking status of the two outliers is not known [20].

\subsection{Hypothesis}

Alterations of EO levels in bipolar disorder appear to be important in the pathogenesis of the illness. There is evidence for both an increase or a decrease in EO concentrations, and there are reasons to believe that each change can lead to the symptoms of the illness (Figure 1). This is an appropriate time to begin the process of translation from basic to clinical research.

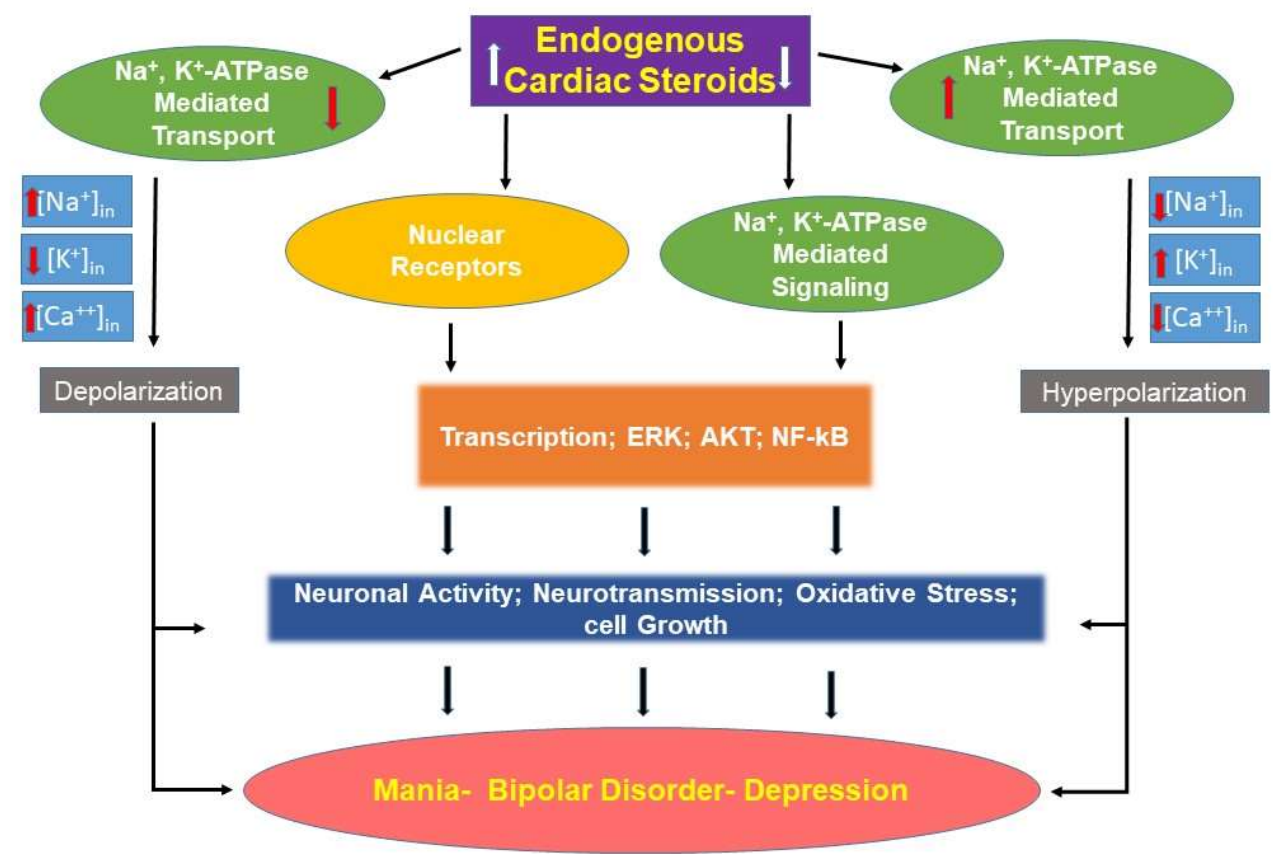

Figure 1. Schematic representation of the possible links between endogenous cardiac steroids and bipolar disorder. See text for details.

\subsection{Translational Implications: Pathophysiologic Models}

The data suggest two parallel but, possibly, competing models. In the first model, some factor (inflammation or physiologic stress) results in increased production of central nervous system EO.

As mentioned above, ECS are known to activate the Src, ERK, and AKT signaling pathways [22,94-96]. These are all signaling systems that have been implicated in BD [97-100]. Additionally, inhibition of sodium pump activity [70] and altering sodium pump isoform expression [72] have been demonstrated in animals receiving ICV ouabain. Activation of signaling pathways occur at levels that do not inhibit sodium pump activity, and this may be important in inducing symptoms of BD. Inactivation of EO with anti-ouabain antibodies would be a reasonable treatment option in this model of relative EO excess (Figure 1).

The second model may have a very similar physiology. In this model, some factor (inflammation or physiologic stress) results in a signal to increase central nervous system EO. However, patients with BD disorder are incapable of upregulating EO under conditions of high demand, and the body experiences a relative EO deficiency (Figure 1). Exogenous ouabain administration would be a reasonable treatment option in this model. Each one of these models will be discussed in additional detail. 


\subsection{EO Excess}

Direct measurements of EO in the parietal cortex of postmortem samples have shown higher levels in BD patients, as compared to those with schizophrenia, major depression, and psychiatrically normal individuals [90]. The increased levels of EO in the brain of BD patients are likely to be brain-region specific, as this increase has not been witnessed in the temporal cortex [89]. Results from one of our laboratories demonstrate that the reduction in brain EO (by intracerebroventricular administration of anti-ouabain antibodies) creates a dramatically protective effect pertaining to a depressive-like behavior in rats [90], with concomitant alterations in catecholamine levels in specific brain regions [79]. Furthermore, a reduction in brain EO also protects against a manic-like behavioral response in an amphetamine (AMPH)-induced mania model [62], with a concomitant reduction of oxidative stress markers [69].

In view of the above, we predicted that the reduction of circulating EO in BD patients might ameliorate their symptoms. Indeed, in a preliminary study, Digibind (Digoxin Immune Fab fragment used for the treatment of digoxin intoxication) was given to six inpatients who were hospitalized for a recurrent episode of bipolar depression. The clinical rating of depression was ascertained using the Montgomery-Asberg Depression Rating Scale (MADRS), before the intervention, and 6, 24, 48, and $72 \mathrm{~h}$ after the intervention. In the results of this experiment, there was an observed decrease in the MADRS score, which reached a peak ( 8.3 points) $24 \mathrm{~h}$ after the administration of Digibind, followed by a gradual return towards baseline scores over the following two days (Zilberstein, A., Krivoy, N., Klein, E. and Lichtstein, D. unpublished observation). These preliminary results, which need to be characterized and extended to more patients, strongly suggest that increased levels of EO are involved in the pathophysiology of the disease and, consequently, their reduction will have beneficial effect.

The mechanisms underlying BD are extremely complex, and the increased ECS levels may be involved in this pathology at various stages and in different biochemical pathways. As mentioned above, it is well established that ECS cause both the inhibition of $\mathrm{Na}^{+}, \mathrm{K}^{+}$-ATPase transport activity and the activation of the Ras-Raf-MEK-ERK signaling cascade, resulting in the activation of MAPK [34]. These two events lead to an increase in intracellular $\mathrm{Ca}^{2+}[101]$, resulting in the opening of mitochondrial ATP-sensitive $\mathrm{K}^{+}$channels and the generation of reactive oxygen species (ROS) [102]. The increase in ROS levels, beyond the capacity of antioxidant defense mechanisms in the brain, damages cellular components, leading to a disruption of normal neuronal function, and this may contribute to the pathological behavioral changes which are characteristic of BD.

\subsection{Relative EO Deficiency}

As previously noted, work in one of our laboratories has identified reduced plasma levels of EO in unmedicated manic patients versus unmedicated controls [80]. Additionally, individuals with BD lack the seasonal variation of EO levels that has been noted in the control subjects who display higher levels in the spring, summer, and autumn (in the range of 400-600 pg digoxin equivalents $/ \mathrm{mL}$ ), and lower levels in the winter (around $150 \mathrm{pg}$ digoxin equivalents $/ \mathrm{mL}$ ), with levels in the range of $150 \mathrm{pg}$ digoxin equivalents $/ \mathrm{mL}$ throughout the entire year [80]. More importantly, euthymic patients with BD do not increase EO levels when they exercise to exhaustion, as has been noted to occur in non-bipolar controls [45] (EO at $60 \mathrm{~min}$ of exercise $0.007 \pm$ S.D. $0.02 \mathrm{ng} / \mathrm{mL}$ in bipolar vs. $0.075 \pm 0.06 \mathrm{ng} / \mathrm{mL}$ in normal control subjects, $p=0.029$, but not significant at peak exercise, $0.009 \pm$ S.D. $0.02 \mathrm{ng} / \mathrm{mL}$ in bipolar vs. $0.131 \pm 0.21 \mathrm{ng} / \mathrm{mL}$ in normal control subjects, $p=0.15$ [81]). In these studies, $\mathrm{BD}$ patients have measurable EO, but it does not vary with physiologic need.

It is proposed that physiological elevations in EO levels that may normally occur with inflammation, severe illness [103], or sleep deprivation [82], do not occur in subjects with $\mathrm{BD}$, and they experience a relative EO deficiency. Considering that physiologic levels of EO activate $\mathrm{Na}^{+}, \mathrm{K}^{+}$-ATPase activity, the relative deficiency results in sodium 
pump hypofunction in relation to the need, and consequent depolarization of neural tissues $[18,21]$.

\subsection{Future Work}

The process of utilizing the EO system as a potential treatment for bipolar disorder holds a lot of promise, but several studies must be performed prior to the proposal of definitive human studies. They include the following:

1. Replication and confirmation of peripheral EO levels, in a larger population of patients with BD both while they are ill and while they are euthymic, are needed to ensure the generalizability of the initial studies. Additionally, the specificity of this effect must be confirmed by examining both psychiatrically ill controls (major depression and schizophrenia), and psychiatrically healthy controls.

2. Examination of brain area-specific EO concentrations in patients and controls. This would utilize postmortem tissues, and this overall process is necessary to make sure that peripheral measurements are reflected in the central nervous system. This is needed to determine if there are brain region-specific alterations. The envisioned treatment protocols are not region-specific, therefore, anatomical localization will help understand untoward side effects of treatment.

3. Utilize neuronal cells obtained from patients and controls (e.g., induced pluripotent cells [104] or olfactory neuroepithelial cells [105]) in order to determine the differential effect (if any) in the response of neural tissue derived from patients with $\mathrm{BD}$ and non-psychiatric controls. Early exploratory evidence from immortalized lymphoblasts [106], induced pluripotent cells, and olfactory neuroepithelial progenitors [107-111], suggests that such differences exist.

As soon as these questions have been answered, clinical studies, with anti-ouabain antibodies (for relative EO excess) or exogenously administered ouabain (for relative EO deficiency; dosing and pharmacokinetics to be determined), can be planned.

\section{Methods}

This is a focused narrative review [112] that presents a comprehensive model of the role of ECS in the etiology of BD. A literature search was conducted in the PubMed database, for clinical and basic research studies, and review articles, published in the time period occurring until December 2021. The PubMed database was searched using the MeSH terms, alone or in combination: 'bipolar disorder', 'bipolar disease', 'ouabain', 'endogenous ouabain', 'cardiac steroids', and 'endogenous cardiac steroids'. In addition, reference lists of identified papers were manually checked for additional related articles. Due to $f$ the comprehensive nature of this review, it includes important historical work, and it draws significantly from the authors' own work because they have been involved in this work for decades.

\section{Conclusions}

Alterations in ECS metabolism in the brain causes numerous biochemical changes that underlie brain dysfunction and mood symptoms. This finding is based on both animal models and translational human results. There are data that demonstrate that excess ECS induce abnormal mood and activity in animals, and there are data suggesting that specific removal of ECS with antibodies normalizes mood. There are also data indicating that circulating levels of ECS are lower in the plasma of manic individuals, and there are data indicating that patients with BD are unable to upregulate synthesis of ECS under conditions that increase their elaboration in non-psychiatric controls. There is strong evidence for the involvement of ion dysregulation and ECS function in bipolar illness. Additional research is required in order to fully characterize these abnormalities and define future clinical directions. 


\begin{abstract}
Author Contributions: Conceptualization, R.S.E.-M. and D.L.; writing-original draft preparation, R.S.E.-M. and D.L.; writing—review and editing, D.L., V.P.S., N.H. and R.S.E.-M.; visualization, D.L.; supervision, R.S.E.-M. and D.L.; project administration, R.S.E.-M.; funding acquisition, D.L. All authors have read and agreed to the published version of the manuscript.

Funding: This work was supported in part by Israel Science Foundation Grant No. 039-4964 to D.L.

Conflicts of Interest: The authors declare no conflict of interest.
\end{abstract}

\title{
References
}

1. Ketter, T.A.; Calabrese, J.R. Stabilization of mood from below versus above baseline in bipolar disorder: A new nomenclature. J. Clin. Psychiatry 2002, 63, 146-151. [CrossRef]

2. Clemente, A.S.; Diniz, B.S.; Nicolato, R.; Kapczinski, F.P.; Soares, J.C.; Firmo, J.O.; Castro-Costa, É. Bipolar disorder prevalence: A systematic review and meta-analysis of the literature. Braz. J. Psychiatry 2015, 37, 155-161. [CrossRef] [PubMed]

3. Grande, I.; Berk, M.; Birmaher, B.; Vieta, E. Bipolar disorder. Lancet 2016, 387, 1561-1572. [CrossRef]

4. Cipriani, G.; Danti, S.; Carlesi, C.; Cammisuli, D.M.; Di Fiorino, M. Bipolar Disorder and Cognitive Dysfunction: A Complex Link. J. Nerv. Ment. Dis. 2017, 205, 743-756. [CrossRef] [PubMed]

5. Dome, P.; Rihmer, Z.; Gonda, X. Suicide risk in bipolar disorder: A brief review. Medicina 2019, 55, 403. [CrossRef] [PubMed]

6. Belvederi Murri, M.; Prestia, D.; Mondelli, V.; Pariante, C.; Patti, S.; Olivieri, B.; Arzani, C.; Masotti, M.; Respino, M.; Antonioli, M. The HPA axis in bipolar disorder: Systematic review and meta-analysis. Psychoneuroendocrinology 2016, 63, 327-342. [CrossRef] [PubMed]

7. Nestler, E.J.; Peña, C.J.; Kundakovic, M.; Mitchell, A.; Akbarian, S. Epigenetic Basis of Mental Illness. Neuroscientist 2016, 22, 447-463. [CrossRef] [PubMed]

8. Takaesu, Y. Circadian rhythm in bipolar disorder: A review of the literature. Psychiatry Clin. Neurosci. 2018, 72, 673-682. [CrossRef]

9. El-Mallakh, R.S.; Yff, T.; Gao, Y. Ion Dysregulation in the Pathogenesis of Bipolar Illness. Ann. Depress. Anxiety 2016, 3, 1076.

10. Askland, K. Toward a biaxial model of "bipolar" affective disorders: Further exploration of genetic, molecular and cellular substrates. J. Affect. Disord. 2006, 94, 35-66. [CrossRef]

11. Judy, J.T.; Zandi, P.P. A review of potassium channels in bipolar disorder. Front. Genet. 2013, 4, 105. [CrossRef] [PubMed]

12. Lichtstein, D.; Ilani, A.; Rosen, H.; Horesh, N.; Singh, S.V.; Buzaglo, N.; Hodes, A. Na ${ }^{+}$, $\mathrm{K}^{+}$-ATPase Signaling and Bipolar Disorder. Int. J. Mol. Sci. 2018, 19, 2314. [CrossRef] [PubMed]

13. Mack, A.A.; Gao, Y.; Ratajczak, M.Z.; Kakar, S.; El-Mallakh, R.S. Review of animal models of bipolar disorder that alter ion regulation. Neurosci. Biobehav. Rev. 2019, 107, 208-214. [CrossRef] [PubMed]

14. Valvassori, S.S.; Dal-Pont, G.C.; Resende, W.R.; Varela, R.B.; Lopes-Borges, J.; Cararo, J.H.; Quevedo, J. Validation of the animal model of bipolar disorder induced by ouabain: Face, construct and predictive perspectives. Transl. Psychiatry $2019,9,158$. [CrossRef] [PubMed]

15. El-Mallakh, R.S.; Huff, M.O. Mood stabilizers and ion regulation. Harv. Rev. Psychiatry 2001, 9, 23-32. [CrossRef]

16. El-Mallakh, R.S.; Paskitti, M.E. The ketogenic diet may have mood-stabilizing properties. Med. Hypotheses 2001, 57, 724-726. [CrossRef]

17. Roberts, R.J.; Repass, R.; El-Mallakh, R.S. Effect of dopamine on intracellular sodium: A common pathway for pharmacological mechanism of action in bipolar illness. World J. Biol. Psychiatry 2010, 11, 181-187. [CrossRef] [PubMed]

18. El-Mallakh, R.S.; Wyatt, R.J. The Na,K-ATPase hypothesis for bipolar illness. Biol. Psychiatry 1995, 37, 235-244. [CrossRef]

19. Looney, S.W.; El-Mallakh, R.S. Meta-analysis of erythrocyte Na,K-ATPase activity in bipolar illness. Depress. Anxiety 1997, 5, 53-65. [CrossRef]

20. Singh, S.V.; Fedorova, O.V.; Wei, W.; Rosen, H.; Horesh, N.; Ilani, A.; Lichtstein, D. Na ${ }^{+}, \mathrm{K}^{+}$-ATPase $\alpha$ isoforms and endogenous cardiac steroids in prefrontal cortex of bipolar patients and controls. Int. J. Mol. Sci. 2020, 21, 5912. [CrossRef] [PubMed]

21. El-Mallakh, R.S.; Gao, Y.; You, P. Role of endogenous ouabain in the etiology of bipolar disorder. Int. J. Bipolar Disord. 2021, 9, 6. [CrossRef] [PubMed]

22. Bagrov, A.Y.; Shapiro, J.I.; Fedorova, O.V. Endogenous cardiotonic steroids: Physiology, pharmacology, and novel therapeutic targets. Pharmacol. Rev. 2009, 61, 9-38. [CrossRef] [PubMed]

23. Hodes, A.; Lichtstein, D. Natriuretic hormones in brain function. Front. Endocrinol. 2014, 5, 201. [CrossRef]

24. Blaustein, M.P.; Hamlyn, J.M. Ouabain, endogenous ouabain and ouabain-like factors: The $\mathrm{Na}^{+}$pump/ouabain receptor, its linkage to NCX, and its myriad functions. Cell Calcium 2020, 86, 102159. [CrossRef]

25. Lichtstein, D.; Steinitz, M.; Gati, I.; Samuelov, S.; Deutsch, J.; Orly, J. Biosynthesis of digitalis-like compounds in rat adrenal cells: Hydroxycholesterol as possible precursor. Life Sci. 1998, 62, 2109-2126. [CrossRef]

26. El-Masri, M.A.; Clark, B.J.; Qazzaz, H.M.; Valdes, R., Jr. Human adrenal cells in culture produce both ouabain-like and dihydroouabain-like factors. Clin. Chem. 2002, 48, 1720-1730. [CrossRef]

27. Blaustein, M.P. The pump, the exchanger, and the holy spirit: Origins and 40-year evolution of ideas about the ouabain-Na ${ }^{+}$ pump endocrine system. Am. J. Physiol. Cell Physiol. 2018, 314, C3-C26. [CrossRef] 
28. Cavalcante-Silva, L.H.A.; Lima, É.A.; Carvalho, D.C.M.; de Sales-Neto, J.M.; Alves, A.K.A.; Galvão, J.G.F.M.; da Silva, J.S.F.; Rodrigues-Mascarenhas, S. Much more than a cardiotonic steroid: Modulation of inflammation by ouabain. Front. Physiol. 2017, 8, 895. [CrossRef]

29. Whayne, T.F., Jr. Clinical use of digitalis: A state of the art review. Am. J. Cardiovasc. Drugs 2018, 18, 427-440. [CrossRef] [PubMed]

30. Ghysel-Burton, J.; Godfraind, T. Stimulation and inhibition of the sodium pump by cardioactive steroids in relation to their binding sites and their inotropic effects on guinea-pig isolated atria. Br. J. Pharmacol. 1979, 66, 175-184. [CrossRef]

31. Lichtstein, D.; Samuelov, S.; Bourrit, A. Characterization of the stimulation of neuronal $\mathrm{Na}^{+}$, $\mathrm{K}^{+}$-ATPase activity by low concentrations of ouabain. Neurochem. Int. 1985, 7, 709-715. [CrossRef]

32. Gao, J.; Wymore, R.S.; Wang, Y.; Gaudette, G.R.; Krukenkamp, I.B.; Cohen, I.S.; Mathias, R.T. Isoform-specific stimulation of cardiac Na/K pumps by nanomolar concentrations of glycosides. J. Gen. Physiol. 2002, 119, 297-312. [CrossRef] [PubMed]

33. Dvela-Levitt, M.; Cohen-Ben Ami, H.; Rosen, H.; Ornoy, A.; Hochner-Celnikier, D.; Granat, M.; Lichtstein, D. Reduction in maternal circulating ouabain impairs offspring growth and kidney development. J. Am. Soc. Nephrol. 2015, 26, 1103-1114. [CrossRef] [PubMed]

34. Xie, Z.; Cai, T. $\mathrm{Na}^{+}-\mathrm{K}^{+}$-ATPase-mediated signal transduction: From protein interaction to cellular function. Mol. Interv. 2003, 3, 157-168. [CrossRef] [PubMed]

35. Bejček, J.; Spiwok, V.; Kmoníčková, E.; Rimpelová, S. Na ${ }^{+} / \mathrm{K}^{+}$-ATPase revisited: On its mechanism of action, role in cancer, and activity modulation. Molecules 2021, 26, 1905. [CrossRef]

36. Wang, Y.; Lonard, D.M.; Yu, Y.; Chow, D.C.; Palzkill, T.G.; Wang, J.; Qi, R.; Matzuk, A.J.; Song, X.; Madoux, F.; et al. Bufalin is a potent small-molecule inhibitor of the steroid receptor coactivators SRC-3 and SRC-1. Cancer Res. 2014, 74, 1506-1517. [CrossRef]

37. Karaś, K.; Sałkowska, A.; Dastych, J.; Bachorz, R.A.; Ratajewski, M. Cardiac glycosides with target at direct and indirect interactions with nuclear receptors. Biomed. Pharmacother. 2020, 127, 110106. [CrossRef]

38. Lichtstein, D.; Rosen, H. Endogenous digitalis-like $\mathrm{Na}^{+}, \mathrm{K}^{+}$-ATPase inhibitors, and brain function. Neurochem. Res. 2001, 26, 971-978. [CrossRef]

39. El-Mallakh, R.S.; Miller, J.; Valdes RJr Cassis, T.B.; Li, R. Digoxin-like immunoreactive factor (DLIF) in human cerebrospinal fluid J. Neuropsychiatry Clin. Neurosci. 2007, 19, 91. [CrossRef]

40. Hamlyn, J.M.; Blaustein, M.P. Endogenous ouabain: Recent advances and controversies. Hypertension 2016, 68, 526-532. [CrossRef]

41. Kaaja, R.J.; Nicholls, M.G. Does the hormone "endogenous ouabain" exist in the human circulation? Biofactors 2018, 44, $219-221$. [CrossRef] [PubMed]

42. Baecher, S.; Kroiss, M.; Fassnacht, M.; Vogeser, M. No endogenous ouabain is detectable in human plasma by ultra-sensitive UPLC-MS/MS. Clin. Chim. Acta 2014, 431, 87-92. [CrossRef]

43. Beasley, C.L.; Honer, W.G.; Bergmann, K.; Falkai, P.; Lütjohann, D.; Bayer, T.A. Reductions in cholesterol and synaptic markers in association cortex in mood disorders. Bipolar Disord. 2005, 7, 449-455. [CrossRef]

44. George, M.S.; Guidotti, A.; Rubinow, D.; Pan, B.; Mikalauskas, K.; Post, R.M. CSF neuroactive steroids in affective disorders: Pregnenolone, progesterone, and DBI. Biol. Psychiatry 1994, 35, 775-780. [CrossRef]

45. Valdes, R.; Hagberg, J.M.; Vaughan, T.E.; Lau, B.W.C.; Seals, D.R.; Ehsani, A.A. Endogenous digoxin-like immunoreactivity in blood is increased during prolonged strenuous exercise. Life Sci. 1988, 42, 103-110. [CrossRef]

46. Antolovic, R.; Bauer, N.; Mohadjerani, M.; Kost, H.; Neu, H.; Kirch, U.; Grünbaum, E.G.; Schoner, W. Endogenous ouabain and its binding globulin: Effects of physical exercise and study on the globulin's tissue distribution. Hypertens. Res. 2000, 23, S93-S98. [CrossRef]

47. Nesher, M.; Shpolansky, U.; Rosen, H.; Lichtstein, D. The digitalis-like steroid hormones: New mechanisms of action and biological significance. Life Sci. 2007, 80, 2093-2107. [CrossRef] [PubMed]

48. Simonini, M.; Casanova, P.; Citterio, L.; Messaggio, E.; Lanzani, C.; Manunta, P. Endogenous ouabain and related genes in the translation from hypertension to renal diseases. Int. J. Mol. Sci. 2018, 19, 1948. [CrossRef] [PubMed]

49. Sajeevadathan, M.; Pettitt, M.J.; Buhr, M. Interaction of ouabain and progesterone on induction of bull sperm capacitation. Theriogenology 2019, 126, 191-198. [CrossRef] [PubMed]

50. Leenen, F.H.H.; Wang, H.W.; Hamlyn, J.M. Sodium pumps, ouabain and aldosterone in the brain: A neuromodulatory pathway underlying salt-sensitive hypertension and heart failure. Cell Calcium 2020, 86, 102151. [CrossRef]

51. Pirkmajer, S.; Bezjak, K.; Matkovič, U.; Dolinar, K.; Jiang, L.Q.; Miš, K.; Gros, K.; Milovanova, K.; Pirkmajer, K.P.; Marš, T.; et al. Ouabain suppresses IL-6/STAT3 signaling and promotes cytokine secretion in cultured skeletal muscle cells. Front. Physiol 2020, 11, 566584. [CrossRef]

52. Ogazon Del Toro, A.; Jimenez, L.; Serrano Rubi, M.; Cereijido, M.; Ponce, A. Ouabain enhances gap junctional intercellular communication by inducing paracrine secretion of prostaglandin E2. Int. J. Mol. Sci. 2021, 22, 6244. [CrossRef]

53. Lichtstein, D.; Rosen, H.; Dvela, M. Cardenolides and bufadienolides as hormones: What is missing? Am. J. Physiol. Renal Physiol. 2012, 302, F957-F958. [CrossRef] [PubMed]

54. Holthouser, K.A.; Mandal, A.; Merchant, M.L.; Schelling, J.R.; Delamere, N.A.; Valdes RJr et, a.l. Ouabain stimulates Na-K-ATPase through a sodium/hydrogen exchanger-1 (NHE-1)-dependent mechanism in human kidney proximal tubule cells. Am. J. Physiol. Renal Physiol. 2010, 299, F77-F90. [CrossRef] [PubMed]

55. Liang, M.; Cai, T.; Tian, J.; Qu, W.; Xie, Z.J. Functional characterization of Src-interacting Na/K-ATPase using RNA interference assay. J. Biol. Chem. 2006, 281, 19709-19719. [CrossRef] 
56. Khundmiri, S.J.; Amin, V.; Henson, J.; Lewis, J.; Ameen, M.; Rane, M.J.; Delamere, N.A. Ouabain stimulates protein kinase B (Akt) phosphorylation in opossum kidney proximal tubule cells through an ERK-dependent pathway. Am. J. Physiol. Cell Physiol. 2007, 293, C1171-C1180. [CrossRef]

57. Khundmiri, S.J.; Ameen, M.; Delamere, N.A.; Lederer, E.D. PTH-mediated regulation of $\mathrm{Na}^{+}-\mathrm{K}^{+}$-ATPase requires Src kinasedependent ERK phosphorylation. Am. J. Physiol. Renal Physiol. 2008, 295, F426-F437. [CrossRef] [PubMed]

58. Kinoshita, P.F.; Yshii, L.M.; Orellana, A.M.M.; Paixão, A.G.; Vasconcelos, A.R.; Lima, L.S.; Kawamoto, E.M.; Scavone, C. Alpha 2 $\mathrm{Na}^{+}, \mathrm{K}^{+}$-ATPase silencing induces loss of inflammatory response and ouabain protection in glial cells. Sci. Rep. 2017, 7, 4894 . [CrossRef]

59. Robbins, T.W.; Sahakian, B.J. Animal models of mania. In Mania: An Evolving Concept; Bellmaker, R.H., Ban Prang, H.M., Eds.; Spectrum: New York, NY, USA, 1980; pp. 143-216.

60. Feier, G.; Valvassori, S.S.; Varela, R.B.; Resende, W.R.; Bavaresco, D.V.; Morais, M.O.; Scaini, G.; Andersen, M.L.; Streck, E.L.; Quevedo, J. Lithium and valproate modulate energy metabolism in an animal model of mania induced by methamphetamine. Pharmacol. Biochem. Behav. 2013, 103, 589-596. [CrossRef]

61. Berggren, U.; Tallstedt, L.; Ahlenius, S.; Engel, J. The effect of lithium on amphetamine-induced locomotor stimulation. Psychopharmacology 1978, 59, 41-45. [CrossRef]

62. Hodes, A.; Rosen, H.; Deutsch, J.; Lifschytz, T.; Einat, H.; Lichtstein, D. Endogenous cardiac steroids in animal models of mania. Bipolar Disord. 2016, 18, 451-459. [CrossRef]

63. Zugno, A.I.; Valvassori, S.S.; Scherer, E.B.; Mattos, C.; Matté, C.; Ferreira, C.L.; Rezin, G.T.; Wyse, A.T.; Quevedo, J.; Streck, E.L. $\mathrm{Na}+\mathrm{K}+-\mathrm{ATPase}$ activity in an animal model of mania. J. Neural. Transm. 2009, 116, 431-436. [CrossRef]

64. Dias, V.T.; Trevizol, F.; Barcelos, R.C.; Kunh, F.T.; Roversi, K.; Schuster, A.J.; Pase, C.S.; Golombieski, R.; Emanuelli, T.; Bürger, M.E. Lifelong consumption of trans fatty acids promotes striatal impairments on $\mathrm{Na}(+) / \mathrm{K}(+)$ ATPase activity and BDNF mRNA expression in an animal model of mania. Brain Res. Bull 2015, 118, 78-81. [CrossRef] [PubMed]

65. Pendyala, G.; Buescher, J.L.; Fox, H.S. Methamphetamine and inflammatory cytokines increase neuronal Na ${ }^{+} / \mathrm{K}^{+}-\mathrm{ATPase}$ isoform 3: Relevance for HIV associated neurocognitive disorders. PLoS ONE 2012, 7, e37604. [CrossRef] [PubMed]

66. Rosenblat, J.D.; McIntyre, R.S. Bipolar disorder and inflammation. Psychiatr. Clin. N. Am. 2016, 39, 125-137. [CrossRef]

67. Khansari, N.; Shakiba, Y.; Mahmoudi, M. Chronic inflammation and oxidative stress as a major cause of age-related diseases and cancer. Recent Pat. Inflamm. Allergy Drug Discov. 2009, 3, 73-80. [CrossRef] [PubMed]

68. Brietzke, E.; Stertz, L.; Fernandes, B.S.; Kauer-Sant'anna, M.; Mascarenhas, M.; Escosteguy Vargas, A.; Chies, J.A.; Kapczinski, F. Comparison of cytokine levels in depressed, manic and euthymic patients with bipolar disorder. J. Affect. Disord. 2009, 116, 214-217. [CrossRef]

69. Hodes, A.; Lifschytz, T.; Rosen, H.; Cohen Ben-Ami, H.; Lichtstein, D. Reduction in endogenous cardiac steroids protects the brain from oxidative stress in a mouse model of mania induced by amphetamine. Brain Res. Bull. 2018, 137, 356-362. [CrossRef]

70. Ruktanonchai, D.J.; El-Mallakh, R.S.; Li, R.; Levy, R.S. Persistent hyperactivity following a single intracerebroventricular dose of ouabain. Physiol. Behav. 1998, 63, 403-406. [CrossRef]

71. El-Mallakh, R.S.; El-Masri, M.A.; Huff, M.O.; Li, X.P.; Decker, S.; Levy, R.S. Intracerebroventricular administration of ouabain as a model of mania in rats. Bipolar Disord. 2003, 5, 362-365. [CrossRef]

72. Hamid, H.; Gao, Y.; Lei, Z.; Hougland, M.T.; El-Mallakh, R.S. Effect of ouabain on sodium pump alpha-isoform expression in an animal model of mania. Prog. Neuro-Psychopharmacol. Biol. Psychiatry 2009, 33, 1103-1106. [CrossRef]

73. Gao, Y.; Jhaveri, M.; Lei, Z.; Chaneb, B.L.; Lingrel, J.; El-Mallakh, R.S. Glial-specific gene alterations associated with manic behaviors. Int. J. Bipolar Disord. 2013, 1, 20. [CrossRef] [PubMed]

74. Clapcote, S.J.; Duffy, S.; Xie, G.; Kirshenbaum, G.; Bechard, A.R.; Rodacker Schack, V.; Petersen, J.; Sinai, L.; Saab, B.J.; Lerch, J.P.; et al. Mutation I810N in the alpha3 isoform of $\mathrm{Na}^{+}, \mathrm{K}^{+}$-ATPase causes impairments in the sodium pump and hyperexcitability in the CNS. Proc. Natl. Acad. Sci. USA 2009, 106, 14085-14090. [CrossRef] [PubMed]

75. Kirshenbaum, G.S.; Clapcote, S.J.; Duffy, S.; Burgess, C.R.; Petersen, J.; Jarowek, K.J.; Yücel, Y.H.; Cortez, M.A.; Snead, O.C., 3rd; Vilsen, B.; et al. Mania-like behavior induced by genetic dysfunction of the neuron-specific $\mathrm{Na}^{+}, \mathrm{K}^{+}$-ATPase $\alpha 3$ sodium pump. Proc. Natl. Acad. Sci. USA 2011, 108, 18144-18149. [CrossRef]

76. Kirshenbaum, G.S.; Clapcote, S.J.; Petersen, J.; Vilsen, B.; Ralph, M.R.; Roder, J.C. Genetic suppression of agrin reduces mania-like behavior in $\mathrm{Na}^{+}, \mathrm{K}^{+}$-ATPase alpha3 mutant mice. Genes Brain Behav. 2012, 11, 436-443. [CrossRef] [PubMed]

77. Hougland, M.T.; Gao, Y.; Herman, L.; Ng, C.K.; Lei, Z.; El-Mallakh, R.S. Positron emission tomography with fluorodeoxyglucoseF18 in an animal model of mania. Psychiatry Res. 2008, 164, 166-171. [CrossRef]

78. Kim, S.H.; Yu, H.S.; Park, H.G.; Jeon, W.J.; Song, J.Y.; Kang, U.G.; Ahn, Y.M.; Lee, Y.H.; Kim, Y.S. Dose-dependent effect of intracerebroventricular injection of ouabain on the phosphorylation of the MEK1/2-ERK1/2-p90RSK pathway in the rat brain related to locomotor activity. Prog. Neuropsychopharmacol. Biol. Psychiatry 2008, 32, 1637-1642. [CrossRef]

79. Goldstein, I.; Lax, E.; Gispan-Herman, I.; Ovadia, H.; Rosen, H.; Yadid, G.; Lichtstein, D. Neutralization of endogenous digitalislike compounds alters catecholamines metabolism in the brain and elicits anti-depressive behavior. Eur. Neuropsychopharmacol. 2012, 22, 72-79. [CrossRef]

80. Grider, G.; El-Mallakh, R.S.; Huff, M.O.; Buss, T.J.; Miller, J.; Valdes, R.J.r. Endogenous digoxin-like immunoreactive factor (DLIF) serum concentrations are decreased in manic bipolar patients compared to normal controls. J. Affect. Disord. 1999, 54, 261-267. [CrossRef] 
81. El-Mallakh, R.S.; Stoddard, M.; Jortani, S.A.; El-Masri, M.A.; Sephton, S.; Valdes, R.J.r. Aberrant regulation of endogenous ouabain-like factor in bipolar subjects. Psychiatry Res. 2010, 178, 116-120. [CrossRef]

82. Gao, Y.; Akers, B.; Roberts, M.B.; El-Mallakh, R.S. Corticosterone response in sleep deprivation and sleep fragmentation. J. Sleep Disord. Manag. 2017, 3, 18. [CrossRef]

83. Puzyński, S.; Beresewicz, M.; Bidzińska, E.; Bogdanowicz, E.; Kalinowski, A.; Koszewska, I.; Swiecicki, L. Reaction to sleep deprivation as a prognostic factor in the treatment of endogenous depression. Psychiatr. Pol. 1991, 25, 83-89, In Polish. [PubMed]

84. Von Treuer, K.; Norman, T.R.; Armstrong, S.M. Overnight human plasma melatonin, cortisol, prolactin, TSH, under conditions of normal sleep, sleep deprivation, and sleep recovery. J. Pineal Res. 1996, 20, 7-14. [CrossRef]

85. Voderholzer, U.; Hohagen, F.; Klein, T.; Jungnickel, J.; Kirschbaum, C.; Berger, M.; Riemann, D. Impact of sleep deprivation and subsequent recovery sleep on cortisol in unmedicated depressed patients. Am. J. Psychiatry 2004, 161, 1404-1410. [CrossRef] [PubMed]

86. Morales, J.; Yáñez, A.; Fernández-González, L.; Montesinos-Magraner, L.; Marco-Ahulló, A.; Solana-Tramunt, M.; Calvete, E. Stress and autonomic response to sleep deprivation in medical residents: A comparative cross-sectional study. PLoS ONE 2019, 14, e0214858. [CrossRef] [PubMed]

87. Song, H.-T.; Sun, X.-Y.; Yang, T.-S.; Zhang, L.-Y.; Yang, J.-L.; Bai, J. Effects of sleep deprivation on serum cortisol level and mental health in servicemen. Int. J. Psychophysiol. 2015, 96, 169-175. [CrossRef] [PubMed]

88. Mynett-Johnson, L.; Murphy, V.; McCormack, J.; Shields, D.C.; Claffey, E.; Manley, P.; McKeon, P. Evidence for an allelic association between bipolar disorder and a $\mathrm{Na}^{+}, \mathrm{K}^{+}$adenosine triphosphatase alpha subunit gene (ATP1A3). Biol. Psychiatry 1998, 44, 47-51. [CrossRef]

89. Hodes, A.; Rosen, H.; Cohen-Ben Ami, H.; Lichtstein, D. $\mathrm{Na}^{+}, \mathrm{K}^{+}$-ATPase $\alpha 3$ isoform in frontal cortex GABAergic neurons in psychiatric diseases. J. Psychiatr. Res. 2019, 115, 21-28. [CrossRef]

90. Goldstein, I.; Levy, T.; Galili, D.; Ovadia, H.; Yirmiya, R.; Rosen, H.; Lichtstein, D. Involvement of $\mathrm{Na}^{+}, \mathrm{K}^{+}-\mathrm{ATPase}$ and endogenous digitalis-like compounds in depressive disorders. Biol. Psychiatry 2006, 60, 491-499. [CrossRef]

91. Goldstein, I.; Lerer, E.; Laiba, E.; Mallet, J.; Mujaheed, M.; Laurent, C.; Rosen, H.; Ebstein, R.P.; Lichtstein, D. Association between sodium- and potassium-activated adenosine triphosphatase alpha isoforms and bipolar disorders. Biol. Psychiatry 2009, 65, 985-991. [CrossRef]

92. Rose, A.M.; Mellett, B.J.; Valdes RJr Kleinman, J.E.; Herman, M.M.; Li, R.; El-Mallakh, R.S. Alpha 2 isoform of the Na,K-adenosine triphosphatase is reduced in temporal cortex of bipolar individuals. Biol. Psychiatry 1998, 44, 892-897. [CrossRef]

93. Saiyad, M.; El-Mallakh, R.S. Smoking is associated with greater symptom load in bipolar disorder patients. Ann. Clin. Psychiatry 2012, 24, 305-309. [PubMed]

94. Miller, C.L.; Yolken, R.H. Methods to optimize the generation of cDNA from postmortem human brain tissue. Brain Res. Brain Res. Protoc. 2003, 10, 156-167. [CrossRef]

95. Xie, Z.; Xie, J. The Na/K-ATPase-mediated signal transduction as a target for new drug development. Front. Biosci. 2005, 10, 3100-3109. [CrossRef]

96. Nguyen, A.N.; Wallace, D.P.; Blanco, G. Ouabain binds with high affinity to the Na,K-ATPase in human polycystic kidney cells and induces extracellular signal-regulated kinase activation and cell proliferation. J. Am. Soc. Nephrol. 2007, 18, 46-57. [CrossRef]

97. Bezchlibnyk, Y.; Young, L.T. The neurobiology of bipolar disorder: Focus on signal transduction pathways and the regulation of gene expression. Can. J. Psychiatry 2002, 47, 135-148. [CrossRef]

98. Chuang, D.M. The antiapoptotic actions of mood stabilizers: Molecular mechanisms and therapeutic potentials. Ann. N. Y. Acad. Sci. 2005, 1053, 195-204. [CrossRef]

99. Cochet-Bissuel, M.; Lory, P.; Monteil, A. The sodium leak channel, NALCN, in health and disease. Front. Cell. Neurosci. 2014, 8, 132. [CrossRef]

100. Schroeder, E.; Gao, Y.; Lei, Z.; Roisen, F.; El-Mallakh, R.S. The gene BRAF is underexpressed in bipolar subject olfactory neuroepithelial progenitor cells undergoing apoptosis. Psychiatry Res. 2016, 236, 130-135. [CrossRef]

101. Altamirano, J.; Li, Y.; DeSantiago, J.; Piacentino V 3rd Houser, S.R.; Bers, D.M. The inotropic effect of cardioactive glycosides in ventricular myocytes requires $\mathrm{Na}^{+}-\mathrm{Ca}^{2+}$ exchanger function. J. Physiol. 2006, 575, 845-854. [CrossRef]

102. Srikanthan, K.; Shapiro, J.I.; Sodhi, K. The role of Na/K-ATPase signaling in oxidative stress related to obesity and cardiovascular disease. Molecules 2016, 21, 1172. [CrossRef]

103. Berendes, E.; Cullen, P.; Van Aken, H.; Zidek, W.; Erren, M.; Hübschen, M.; Weber, T.; Wirtz, S.; Tepel, M.; Walter, M. Endogenous glycosides in critically ill patients. Crit. Care Med. 2003, 31, 1331-1337. [CrossRef]

104. Liu, Y.N.; Lu, S.Y.; Yao, J. Application of induced pluripotent stem cells to understand neurobiological basis of bipolar disorder and schizophrenia. Psychiatry Clin. Neurosci. 2017, 71, 579-599. [CrossRef] [PubMed]

105. Gao, Y.; Winstead, W.I.; Lei, Z.; Lu, C.; Roisen, F.J.; El-Mallakh, R.S. Olfactory neuroepithelial neural progenitor cells from subjects with bipolar I disorder. J. Cent. Nerv. System Dis. 2017, 9, 1179573517694529. [CrossRef] [PubMed]

106. Li, R.; El-Mallakh, R.S. Differential response of bipolar and normal control lymphoblastoid cell sodium pump to ethacrynic acid. J. Affect. Disord. 2004, 80, 11-17. [CrossRef]

107. Huang, X.; Lei, Z.; El-Mallakh, R.S. Lithium normalizes elevated intracellular sodium. Bipolar Disord. 2007, 9, 298-300. [CrossRef] 
108. Willett, L.; Gao, Y.; Lei, Z.; Lu, C.; Roisen, F.J.; Winstead, W.I.; El-Mallakh, R.S. Effects of brain-derived neurotrophic factor on sodium-induced apoptosis in human olfactory neuroepithelial progenitor cells. Psychiatry Res 2010, 178, 391-394. [CrossRef] [PubMed]

109. Gao, Y.; Lei, Z.; Lu, C.; Roisen, F.J.; El-Mallakh, R.S. Effect of ionic stress on apoptosis and the expression of TRPM2 in human olfactory neuroepithelial-derived progenitors. World J. Biol. Psychiatry 2010, 11, 972-984. [CrossRef] [PubMed]

110. Gao, Y.; Lohano, K.; Delamere, N.A.; Lei, Z.; El-Mallakh, R.S. Ethanol normalizes glutamate-induced elevation of intracellular sodium in olfactory neuroepithelial progenitors from subjects with bipolar illness but not nonbipolar controls: Biologic evidence for the self-medication hypothesis. Bipolar Disord. 2019, 21, 179-181. [CrossRef]

111. Viswanath, B.; Jose, S.P.; Squassina, A.; Thirthalli, J.; Purushottam, M.; Mukherjee, O.; Vladimirov, V.; Patrinos, G.P.; Del Zompo, M.; Jain, S. Cellular models to study bipolar disorder: A systematic review. J. Affect. Disord. 2015, 184, 36-50. [CrossRef]

112. Green, B.N.; Johnson, C.D.; Adams, A. Writing narrative literature reviews for peer-reviewed journals: Secrets of the trade. J. Chiropr. Med. 2006, 5, 101-117. [CrossRef] 